NBER WORKING PAPER SERIES

\title{
DE-GLOBALIZATION: \\ DRIVEN BY GLOBAL CRISES?
}

\author{
Assaf Razin \\ Working Paper 27929 \\ http://www.nber.org/papers/w27929
}

\author{
NATIONAL BUREAU OF ECONOMIC RESEARCH \\ 1050 Massachusetts Avenue \\ Cambridge, MA 02138 \\ October 2020
}

The views expressed herein are those of the author and do not necessarily reflect the views of the National Bureau of Economic Research.

NBER working papers are circulated for discussion and comment purposes. They have not been peer-reviewed or been subject to the review by the NBER Board of Directors that accompanies official NBER publications.

(C) 2020 by Assaf Razin. All rights reserved. Short sections of text, not to exceed two paragraphs, may be quoted without explicit permission provided that full credit, including $\bigcirc$ notice, is given to the source. 
De-globalization: Driven by Global Crises?

Assaf Razin

NBER Working Paper No. 27929

October 2020

JEL No. F0,F3

\title{
$\underline{\text { ABSTRACT }}$
}

International trade increased rapidly after 1990 , fueled by the growth of a complex network of global value chains. Financial globalization gathered force. Trade globalization, however, reversed course since the Global Financial Crisis. The new trend is expected to endure after the Global Pandemic Crisis. There is no indication so far of significant reversal of financial globalization.

\author{
Assaf Razin \\ Eitan Berglas School of Economics \\ Tel Aviv University \\ Tel Aviv 69978 \\ ISRAEL \\ and Cornell University and CEPR \\ and also NBER \\ razin@tauex.tau.ac.il
}


In his 1919 book, The Economic Consequences of the Peace, John Maynard Keynes described the open borders of the then bygone first age of globalization before WWI. He writes: “The inhabitant of London could order by telephone, sipping his morning tea in bed, the various products of the whole earth, in such quantity as he might see fit, and reasonably expect their early delivery on his doorstep, he could at the same moment and by the same means adventure his wealth in the natural resources and new enterprises of any quarter of the world, [and] he could secure forthwith, if he wished it, cheap and comfortable means of transit to any country or climate without passport or other formality.” Globalization did reverse its course in the second period, from the outbreak of World War I in 1914 until the end of World War II in 1945. World War I produced prolonged economic dislocation, which included the withdrawal of Russia from world trade after the communist revolution in 1917, the Spanish flu pandemic in 1918 and 1919, monetary instability in the early 1920s, new immigration restrictions, the Great Depression starting in 1929, and a severe outbreak of protectionism in the 1930s. Health concerns are providing new rationales for protectionism, especially for international travel, medical gear and food, and a renewed emphasis on domestic sourcing. “History Does Not Repeat Itself, But It Rhymes”, said Mark Twain. Value supply chains are highly vulnerable to pandemics because they are geographically vastly expanded. They are sensitive also politically caused trade conflicts. Even prior to the Corona virus pandemic, trade globalization was challenged by a rising wave of populism spurred on by 
economic discontent in Europe, the United States, Latin America and elsewhere and a trade war between the US and China .

The recent backlash against trade globalization is not a new phenomenon, either. International trade increased rapidly after 1990, fuelled by the growth of a complex network of global value chains (GVCs). These chains represent the process of ever-finer specialization and geographic fragmentation of production. Generally speaking, the higher the participation in intra-regional value chains, the higher the degree of regional economic integration. Likewise, the higher the degree of participation in inter-regional GVCs, the higher the degree of economic integration into the global economy. In the wake of the 2008 Global Financial Crisis, uncertainty in the world economy led many firms to reassess their business models. Rather than relying on global supply chains, an increasing number of firms invested in robots, which prompted a renaissance of manufacturing in industrialized countries. The global value chains could be reshuffled, or be reduced. Whether they will be localized or regionalized, or whether the crisis will lead to the continuation of globalization. A short period of economic recession seems unavoidable, but the question is whether the increased frequency of pandemics in the $21^{\text {st }}$ century crisis will structurally transform globalization on the long-term.

The pandemic-induced slump in economic activity is deep. Consumer spending, investment spending, and export demand tumble. Central banks are tied down by zero interest rate are losing its most effective stabilization- policy instrument. Consequently, the burden falls on fiscal policy. When the coronavirus hit, supply chains and production have been disrupted. However, the bigger impact of the pandemic has been on the demand side, the desire to invest has plunged, while people across the rich world are now saving much of their income. 
Longer-term there is a risk that younger student from poorer backgrounds in the future will struggle to catch up after an extensive period out of school due to lockdowns and other disruptions. Education disruptions by the pandemic distorts the development trajectory of children, social mobility declines, lowering productivity and raising inequality.

\section{Growth and Global Crises: History}

Carmen Reinhart and Kenneth Rogoff (2014), surveying centuries old crises, have discovered startling qualitative and quantitative parallels across a number of standard financial crisis indicators in 18 postwar banking crises. They found that banking crises were protracted (output declining on average for two years); asset prices fell steeply, with housing plunging 35 percent on average, and equity prices declining by 55 percent over 3.5 years. Unemployment rises by 7 percentage points over four years, while output falls by 9 percent. 


\section{Figure 1: Global Growth 1871-2020}

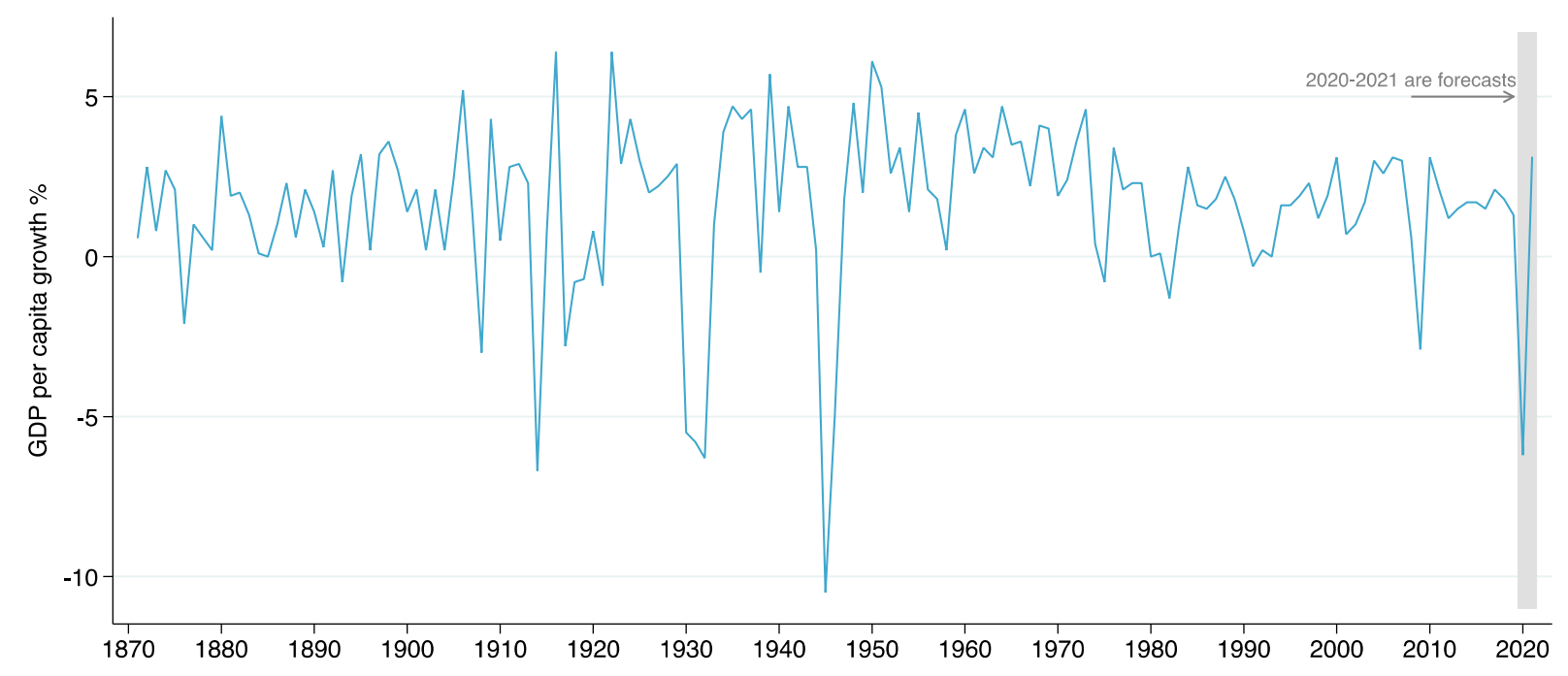

Source: World Bank (2020), Global Economic Prospects.

Since 1870, the global economy has experienced 14 global recessions. Current projections imply that the COVID-19 global recession will be the fourth deepest in this period and the most severe since the end of World War II.

\section{The Global Financial Crisis and the Pandemic Crisis}

Figure 5 shows the index of world industrial production during the months following the onset of these three crises (June 1929 for the Great Depression, April 2008 for the Great Recession, and March 2020 for the Pandemic Global Crisis).

It tracks pathways in the initial phases of several global crises. 
Figure 2: World industrial production, Great Depression vs. Global Financial Crisis

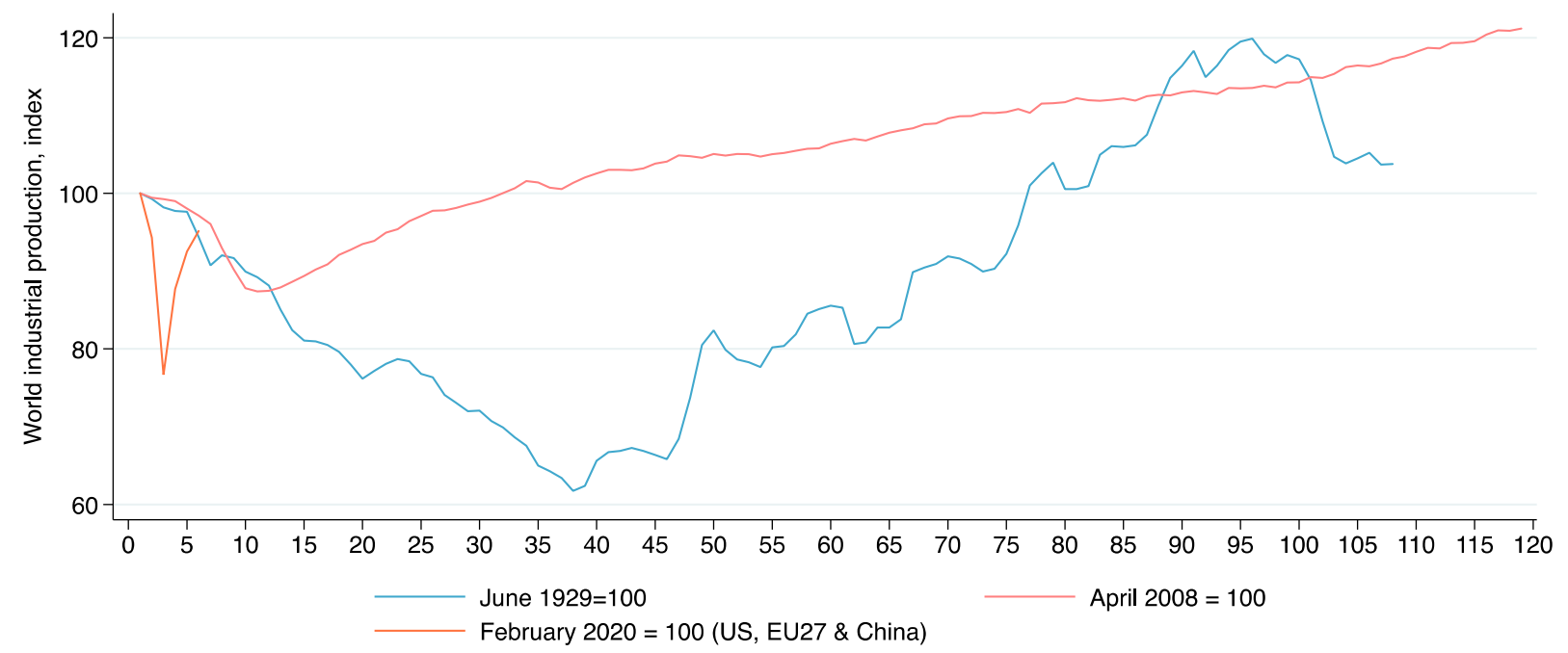

Source: Updated dataset of Eichengreen and O'Rourke (2010). Recent data for US and EU are taken from the OECD (2020), the Chinese data taken from the National Bureau of Statistics of China (Press release, August 2020). Indices are weighted by 2019 real GDP (in PPP terms) from the OECD.

Eichengreen and O’Rourke (2010) observe that the downturns following the two financial crises, The Great Depression and the Great Financial Crisis, were initially very similar.

The first year of the 2008-2009 slump in industrial production (and, indeed in trade in other charts, not shown, that they produced), was fully comparable to the first year of the great global slump from 1929 to 1933. The Global Financial Crisis has some similarities with the Great Depression. It appears that in both cases the trigger is a credit crunch following a sudden burst of asset-price and credit bubbles. However, differences financial institutions and policy reactions may explain the divergence of tracks after the initial stages. Recovery of world industrial production starts much earlier in the Great Recession than in the Great Depression. Periods of depressed output are significantly shorter in the former than the latter, thanks to different policy reactions and improved financial and budget institutions. The difference between the global crises occurred after about ten 
months. During the Great Recession, there was a relatively quick recovery after ten months. Such a recovery did not occur during the Great Depression. The downturn would continue for another 25 months before the recovery set in. The fundamental reason for the sharp contrast between these two crises in terms of recovery periods was the different reactions of monetary and fiscal authorities. In comparing the 2008 Global Financial Crisis (GFC) to the 2020 Pandemic Global Crisis (PGC) there are few key differences:

Origin of crisis. The shock that stated the GFC was an internal to the economy. The crisis originated from the malfunctioning of the economy's financial system. In contrast, the shock, which started and prolonged PC, was external to the economy. Epidemiology forces drive the crisis.

Magnitude of the initial shock. Quantitatively, the first quarters decline since the inception of the crisis, in employment and output, are greater in the PC case, compared to the GFC case.

Length of recovery. The recovery period from PC, once immunity from coronavirus is discovered and covered large segments of the population, is expected to be quick. In contrast, the recovery period in the GFC case was protracted.

\title{
Unemployment and Disaster-Relief Fiscal Policy
}

\author{
Figure 3: US gross domestic product: Percentage change from previous
}


Quarter, 1950-2020 2nd quarter)

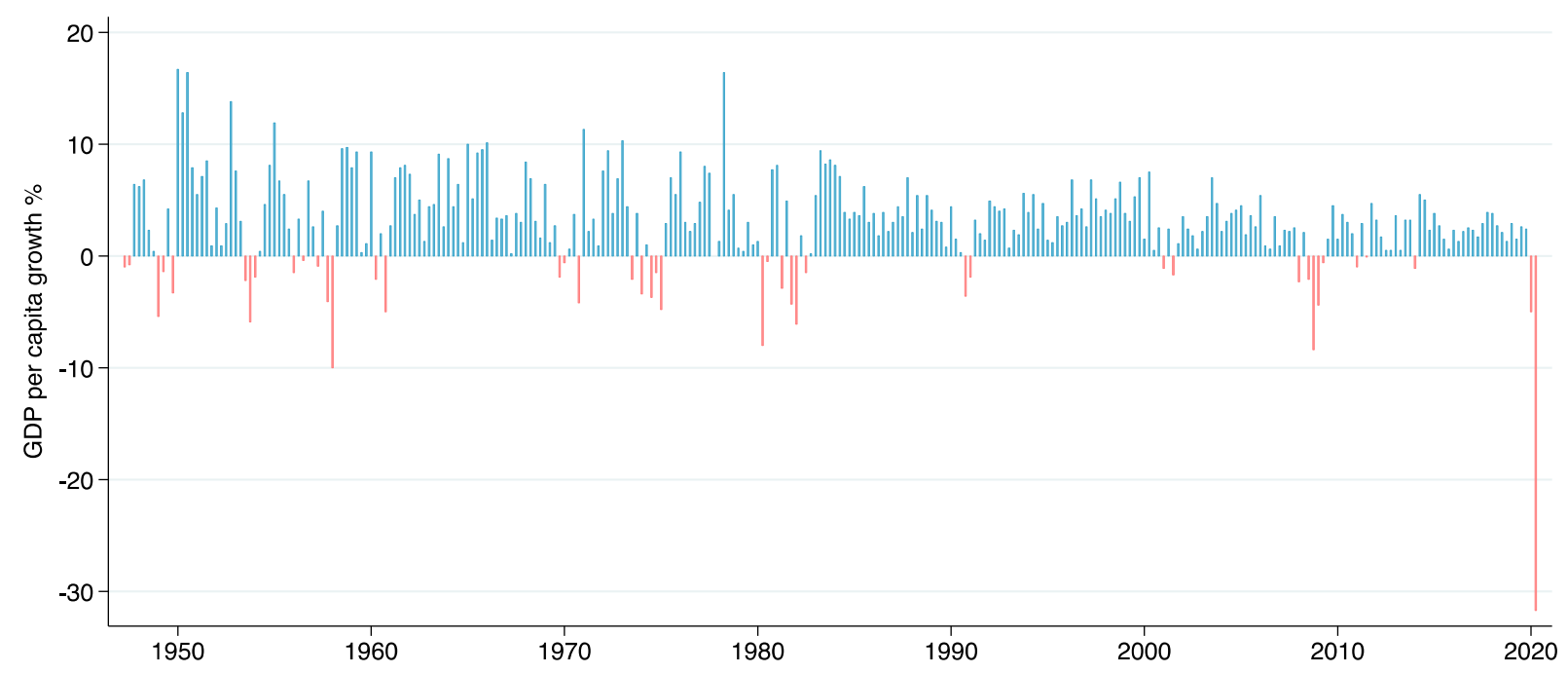

Source: US Bureau of Economic Analysis (2020)

\section{Employment}

Figure 4: US Unemployment rate since 1948

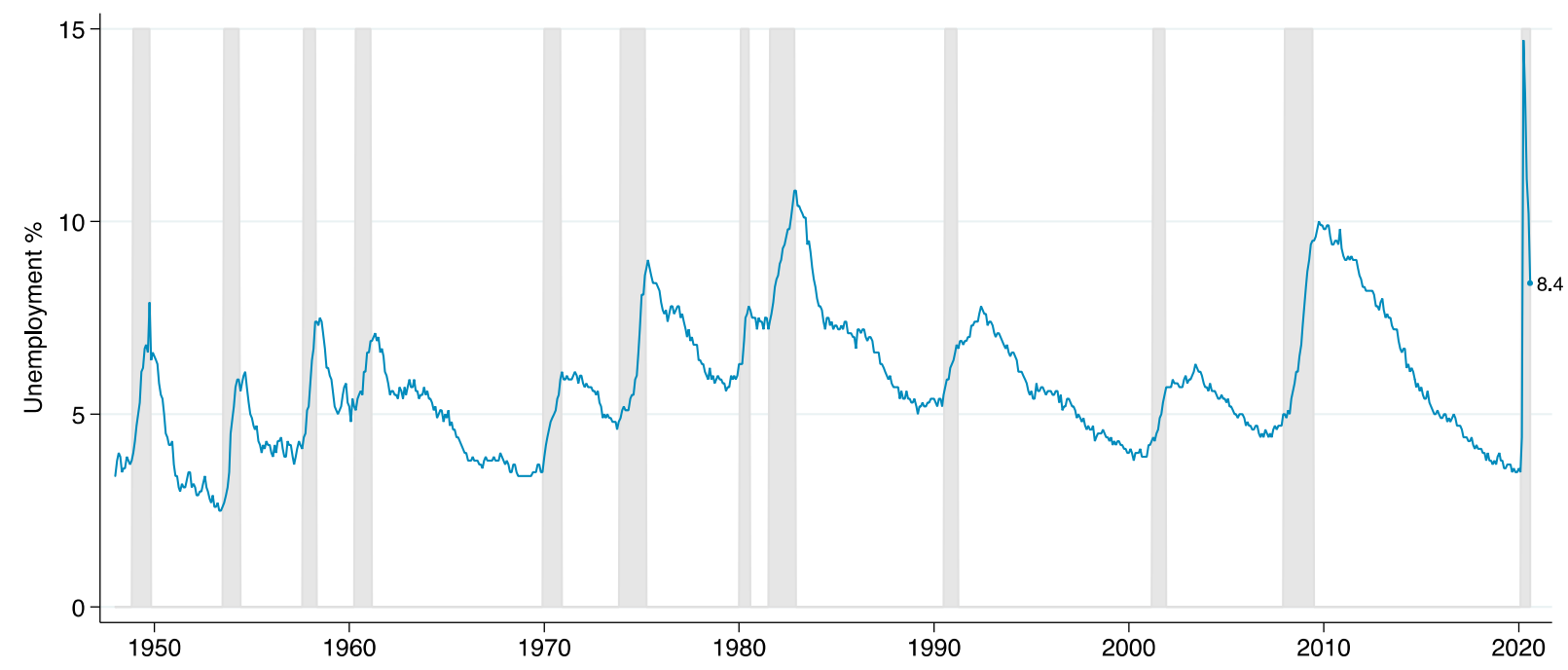

Source: Bureau of Labor Statistics and the Federal Reserve Economic Data. Unemployment rates are seasonally adjusted. 
Pandemic lockdowns brought the unemployment rate to an historical highest (see Figure 3). Exiting from the lockdown U.S. jobs grew by 4.8 million in June 2020. It was the second month of strong job gain after the lockdown huge losses, when businesses laid off or furloughed tens of millions of workers as the pandemic put a large swath of economic activity on ice. The employment rebound came in part thanks to more than $\$ 500$ billion in federal aid to small businesses offered on the condition that workers be retained, under the one-off Paycheck Protection Program.

The "keep- heads- above-water" policy response has been massive and quick among advanced economies. The European style is trying to preserve firms and workers in their current jobs and the U.S. version is to try to address it as a natural catastrophe and try to subsidize people but allow higher unemployment. In the US, Cares Act legislation was aimed at providing relief for individuals and businesses that have been negatively impacted by the coronavirus outbreak. ${ }^{2}$ The CARES program included:

Direct payments: Americans who pay taxes will receive a one-time direct deposit of up to $\$ 1,200$, and married couples will receive $\$ 2,400$, plus an additional $\$ 500$ per child. The payments will be available for incomes up to $\$ 75,000$ for individuals and $\$ 150,000$ for married couples.

Unemployment: the program provides $\$ 250$ billion for an extended unemployment insurance program, expands eligibility, and offers workers an additional \$600 per week for four months, on top of what state programs pay. It also extends UI benefits through Dec. 31 for eligible workers. The program applies to the self-employed, independent contractors and gig economy workers.

Payroll taxes: The measure allows employers to delay the payment of their portion of 2020 payroll taxes until 2021 and 2022. 
Use of retirement funds: The bill waives the $10 \%$ early withdrawal penalty for distributions up to $\$ 100,000$ for coronavirus-related purposes, retroactive to Jan. 1, 2020. Withdrawals are still taxed, but taxes are spread over three years, or the taxpayer has the three-year period to roll it back over.

The PPP Act offered small businesses loans that can be converted into grants if they are used to maintain payroll. US Bureau of Labor Statistics (May 2020 report) shows a partial bounce back of contact-intensive sectors like restaurants and dentists' offices that were largely shut down by social distancing, Welfare states reacted with many job maintenance and firm relief measures have been implemented during the Great Lockdown. In both the EU and the US tax deadlines have been pushed back. Many US states waived the one-week 'waiting period' before receiving unemployment benefits and the job search requirement. They expanded eligibility to include those who need to stay home to take care of either a child (due to daycare and school closures) or other dependent, who may be sick/quarantined, and those who are themselves sick or quarantined due to suspicion of being sick. The UK government is further putting in place government-backed, subsidized loans to help small businesses weather the storm. The French government is extending its 'chômage partiel' (temporary unemployment) program, effectively covering $85 \%$ of wages. Germany's stimulus package centerpiece includes a three percentage-point reduction in value added tax, valid from June 2020 until the end of 2020. .In addition, the coalition partners signed off on a $€ 50 \mathrm{bn}$ "future package" of investment, with a focus on the transition to a greener economy, and research in areas such as artificial intelligence and quantum computing. Huge sums will be spent on expanding Germany's charging infrastructure for electric cars. Since the VAT is equivalent to a tax on wages, plus a tax on wealth the cut in VAT boost consumption spending and provides incentive to work. It also has an intertemporal stimulating effect. The government changes VAT rates to create a future path of increasing sales taxes and hence stimulate inflation expectations and Real-Time Evidence 
Chetty et Al (2020) use daily credit card data to provide real-time evidence on impacts of the Covid-19 Pandemic. ${ }^{3}$ They find that in the first few months of the pandemic, spending fell much more for the rich than the poor (top $25 \%$ vs. bottom $25 \%$ ), and the bulk of the reduction resulted from a drop in spending on in-person services. This indicates there was not necessarily a reduction in purchasing power. The reduction was related to fears of the virus. Business revenue dropped more severely in high-income areas. The authors' interpretation is that this is a supply shock, not a lack of purchasing power.

CARES Act stimulus increased spending, but did not fill the hole created by the pandemic shock. Stimulus checks did increase spending among low-income Americans, but the vast majority of the increase in spending was on durable goods, not in-person services. For stimulus to have an impact on employment in the short-run, people would have to switch jobs or move.

The Paycheck Protection Program (PPP) had limited impact on employment. The authors suggest that businesses who took the loans did not expect to lay off workers to begin with. Effects of this shock on employment and inequality may be long lasting and require policy interventions. $70 \%$ of low-income workers who had jobs in wealthy parts of Manhattan lost their jobs. Chetty cites evidence, from past studies of the Great Recession that people do not often move in search of new jobs; suggesting policy intervention may be required. Further, there are potentially big implications for inequality. One example: Low-income students are doing far fewer math exercises on commonly used app than their higher-income peers are.

\section{Financial Globalization}

\footnotetext{
${ }^{3}$ Economists often study the effects of shocks with household survey data, but these data-while important-have limitations. First, they have time lags and low frequencies. Second, they cannot be disaggregated.
} 
Full international financial integration requires that in the long run (when prices adjust to various shocks and markets clear), the following arbitrage equation holds.

$$
1+r_{t}^{U S}=\left(1+r_{t}^{i}\right) \frac{q_{i / U S, t+1}}{q_{i / U S, t}}
$$

Where $i$ stands for Israel, Canada, Germany and the United Kingdom; and q stands for the real exchange rate Vis $a$ Vis the US dollar ${ }^{4}$ :

$$
q_{i / U S, t}^{t}=E_{i / U S, t} \frac{P_{U S, t}}{P_{i, t}}
$$

In addition, $E$ stands for the nominal exchange rate, Vis a Vis the US dollar; and $P$ stands for the price level.

The next Figure plots the graphs of the real-interest-rate, adjusted for real exchange rate changes, the yields on three-month government bonds for Israel, Canada, Germany and the United Kingdom, and the yields on three-month US government bonds. International financial integration generates more synchronized country-specific yields. Time series are filtered to wash out short-run idiosyncratic fluctuations. Figure 7 demonstrates strikingly that in the 1990s Israel integrates sufficiently into the world capital market, while convergence occurred at the beginning of the 2000s.

${ }^{4}$ Recall that by the Fisher equation:

$$
1+r_{t}^{U S}=\left(1+i_{U S}^{t}\right) \frac{P_{U S, t}}{P_{U S, t+1}}, \text { That is, }\left(1+r_{t}^{i}\right) \frac{q_{i / U S, t+1}}{q_{i / U S, t}}=\left(1+i_{i}^{t}\right) \frac{P_{i, t}}{P_{i, t+1}} \frac{q_{i / U S, t+1}}{q_{i / U S, t}} .
$$


Figure 5: Gross Real Interest Rate Adjusted for Real Exchange Rate Changes (US benchmark)

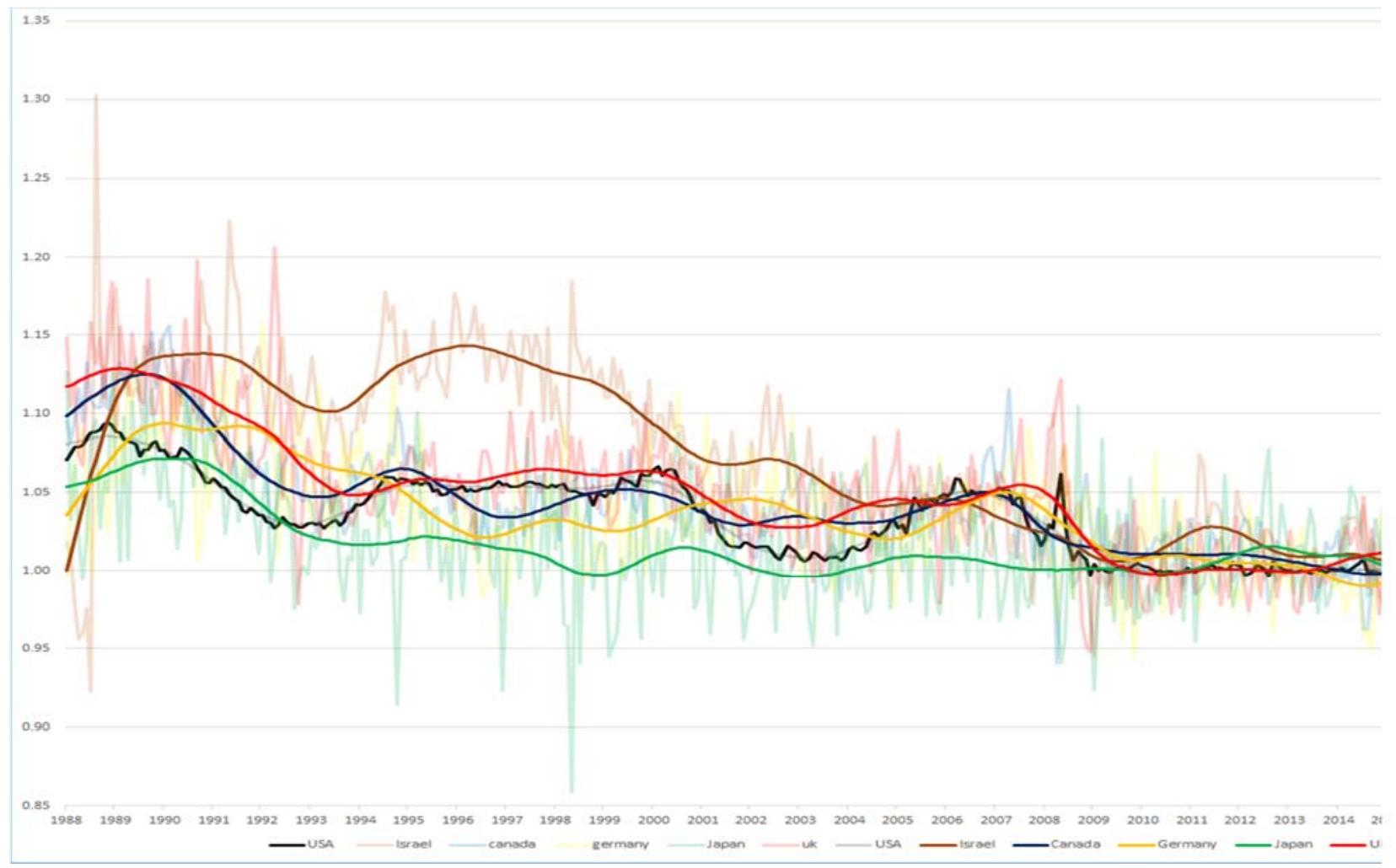

Note: Series are HP-filtered. Monthly data are shown in the background.

Source: Stats Bureau, FRED, World Bank, Real-exchange-rate adjusted, yields on threemonth government bonds for Israel, Canada, Germany and the United Kingdom, and the yields on three-month US government bonds.

The cross-country dispersion measure, shown in Figure 7, describes a downward trend, except for a short-term blip during the Great Financial Crisis.

Figure 6: Cross-country standard Deviation of real interest rates adjusted for exchange rate changes

Source: Stats Bureau, FRED, World Bank, Real-exchange-rate adjusted, yields on three-month government bonds for Israel, Canada, Germany and the United Kingdom, and the yields on three-month US government bonds. 


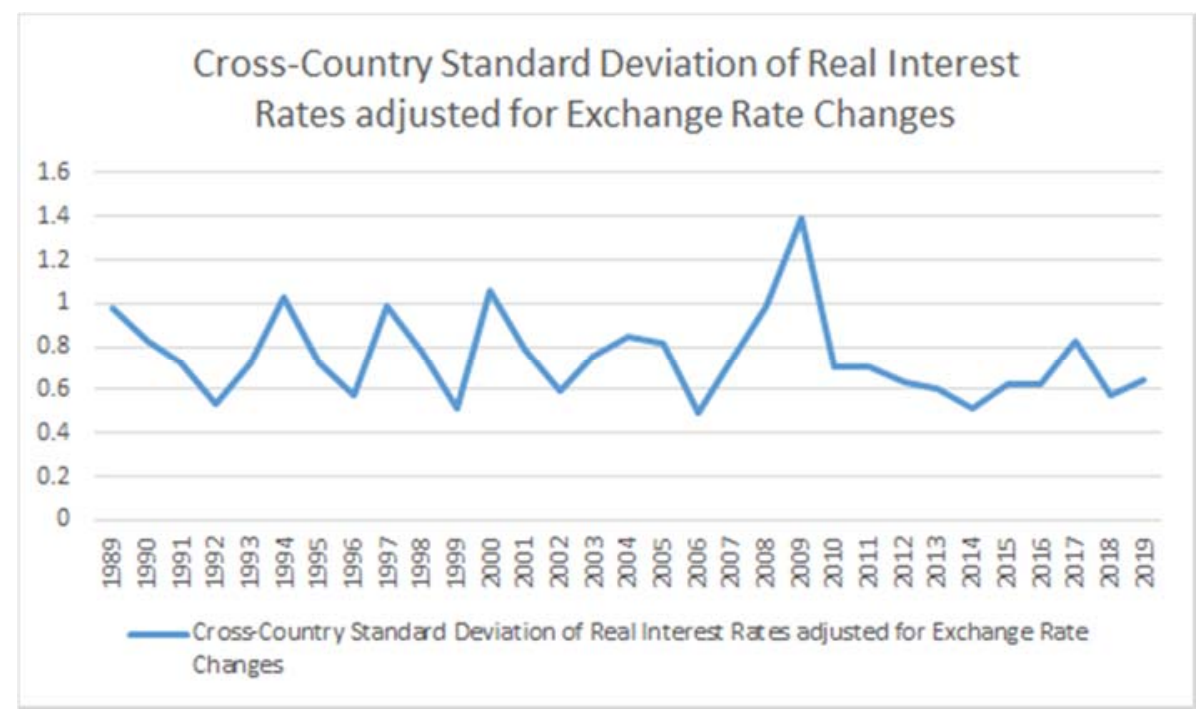

Source: Stats Bureau, FRED, World Bank, Real-exchange-rate adjusted, yields on three-month government bonds for Israel, Canada, Germany and the United Kingdom, and the yields on three-month US government bonds.

In sum, Figure 6 and 7 bring out a strong evidence for financial integration among advanced economies. Figure 8 describes the US and Israel dispersion, indicating a narrowing gaps over time. $^{5}$

Figure 8: Israel-US Standard deviation of interest rate adjusted for exchange rate changes

\section{Trade-Globalization in Retreat}

\footnotetext{
${ }^{5}$ In the Appendix we depict the cross country trend of standard deviation of Israel's real interest rates adjusted for exchange rate changes and the US real interest rate.
} 
Trade creates more complex global inflation dynamics. The ICT revolution has made a great unbundling of production chains possible, and large wage differentials globally have made doing so profitable. This generated vast new quantity of 'supply chain trade' Greater international economic interconnectedness over recent decades has been changing inflation dynamics.6 The expansion of global value chains (GVCs), i.e., cross-border trade in intermediate goods and services, is an important channel through which global economic slack influences domestic inflation.7 They argue that as GVCs expand, direct and indirect competition among economies increases, making domestic inflation more sensitive to the global output gap. This can affect the trade-offs that central banks face when managing inflation. The slope of the Phillips Curve may have changed.8 There is evidence that global inflationary cycles that correspond with an intensifying globalization propagates common shocks via commodity, trade and financial channels. Correlations of $\mathrm{CPI}$ are as elevated today as during the first oil shock and on the surface we appear to be in the midst of a highly synchronized global rates cycle.

A measure of financial integration is how close is the country's real interest, adjusted for real exchange rate evolution into the next period, is equal across countries, which use different currencies and have different domestic price adjustments processes. In the long run (when domestic price adjustments to shocks takes place), under perfect international arbitrage,

Global value chains will likely undergo a drastic transformation in the decade ahead. The change will be driven by a push for greater supply chain resilience due to the pandemic.

One aspect of a lack of resilience of the last decades of globalization to pandemic is that global value chains that were highly vulnerable. They were not sufficiently diversified. They were sensitive to interruptions caused by either a pandemic like this one or trade conflicts. Even prior

\footnotetext{
${ }^{6}$ See Carney (2017).

${ }^{7}$ See Auer et al (2017).

${ }^{8}$ See Razin (2018).
} 
to the Corona virus pandemic, trade globalization was challenged by a rising wave of populism spurred on by economic discontent in Europe, the United States, Latin America and elsewhere and a trade war between the US and China. The recent backlash against trade globalization is not a new phenomenon, either. International trade increased rapidly after 1990, fueled by the growth of a complex network of global value chains (GVCs). These chains represent the process of ever-finer specialization and geographic fragmentation of production. Kilic and Marin (2020) distinguish between local value chain participation, regional value chain (RVC) participation and global value chain (GVC) participation. Generally speaking, the higher the participation in intra-regional RVCs, the higher the degree of regional economic integration. Likewise, the higher the degree of participation in inter-regional GVCs, the higher the degree of economic integration into the global economy. In the wake of the 2008 Global Financial Crisis, uncertainty in the world economy led many firms to reassess their business models. Rather than relying on global supply chains, an increasing number of firms invested in robots, which prompted a renaissance of manufacturing in industrialized countries. The global value chains could be reshuffled, or be reduced. Whether they will be localized or regionalized, or whether the crisis will lead to the continuation of globalization. A short period of economic recession seems unavoidable, but the question is whether COVID-19 crisis will structurally transform globalization on the long-term. Unemployment patterns differ markedly from the experience of the Great Recession that began in 2008.

Global trade, measured by the ratio of world exports to world GDP, is a proxy for economic integration. Figure 7 reveals five periods of modern globalization (see Irwin (2013)). 
Figure 7: Ratio of world exports to world GDP: 1870-2007



Source: Our World in Data, “Globalization over 5 centuries, World”.

The pandemic is expected to add further momentum to the de-globalization trend. The forecasted diminished world trade in goods is shown in Figure 8.

\section{Figure 8: Volume of world merchandise trade}

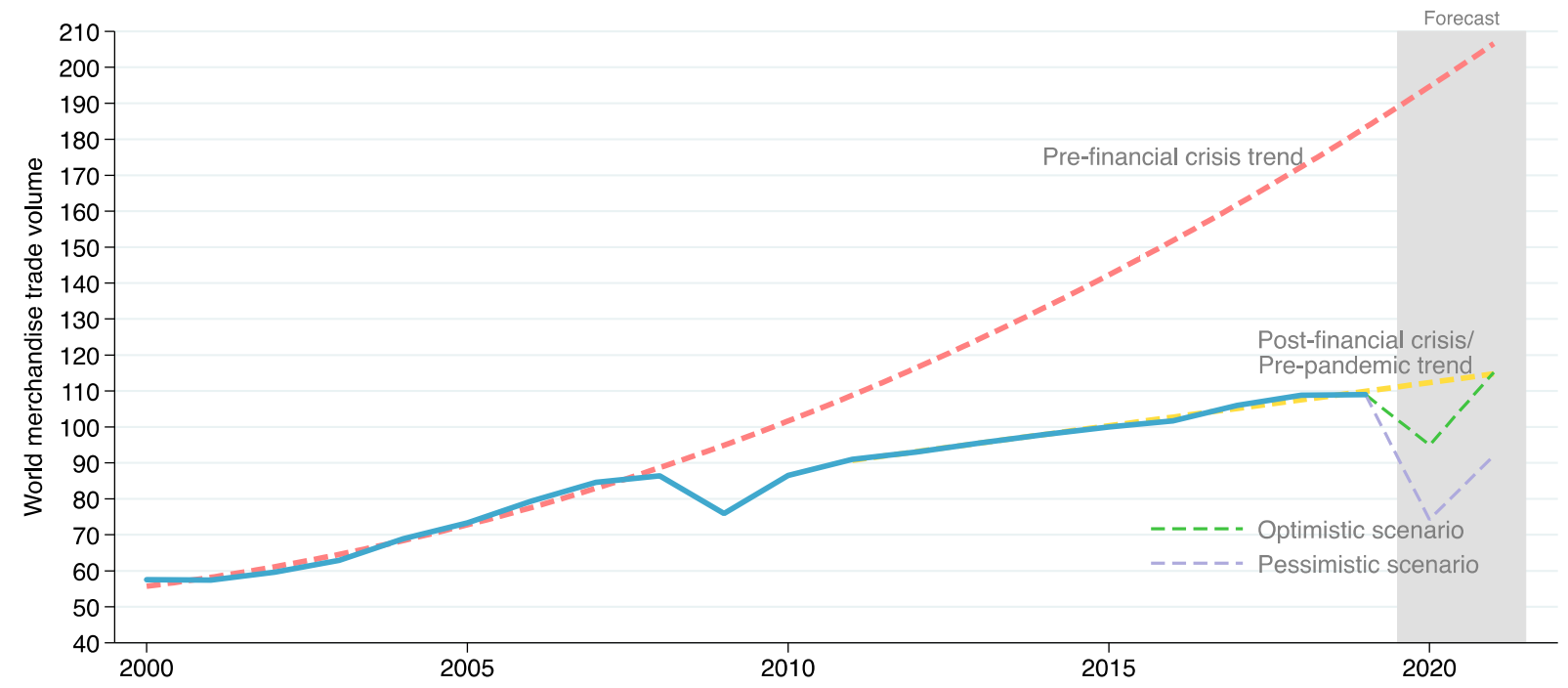

Source: WTO, Merchandise export volume indices. 
Disparities in the 2020 pandemic US unemployment across different demographic groups. The largest employment declines during the pandemic to date are among Hispanics, younger workers and workers who have a high school degree or some college education but have not completed a college degree.

Social distancing is more difficult for workers in the service sector and unemployment rates are higher for some service sector occupations like food service and travel. Workers in jobs where face-to-face interactions are difficult to avoid are significantly more likely to have been unemployed.

World Investment Report has monitored FDI and the activities of multinational enterprises for 30 years, during which time international production saw two decades of rapid growth followed by a decade of stagnation. Flows of cross-border investment in physical productive assets stopped growing in the 2010s, the growth of trade slowed down and global value chain (GVC) trade declined (figure 9) ${ }^{9}$.

\section{Figure 9 : Global Value Chain}

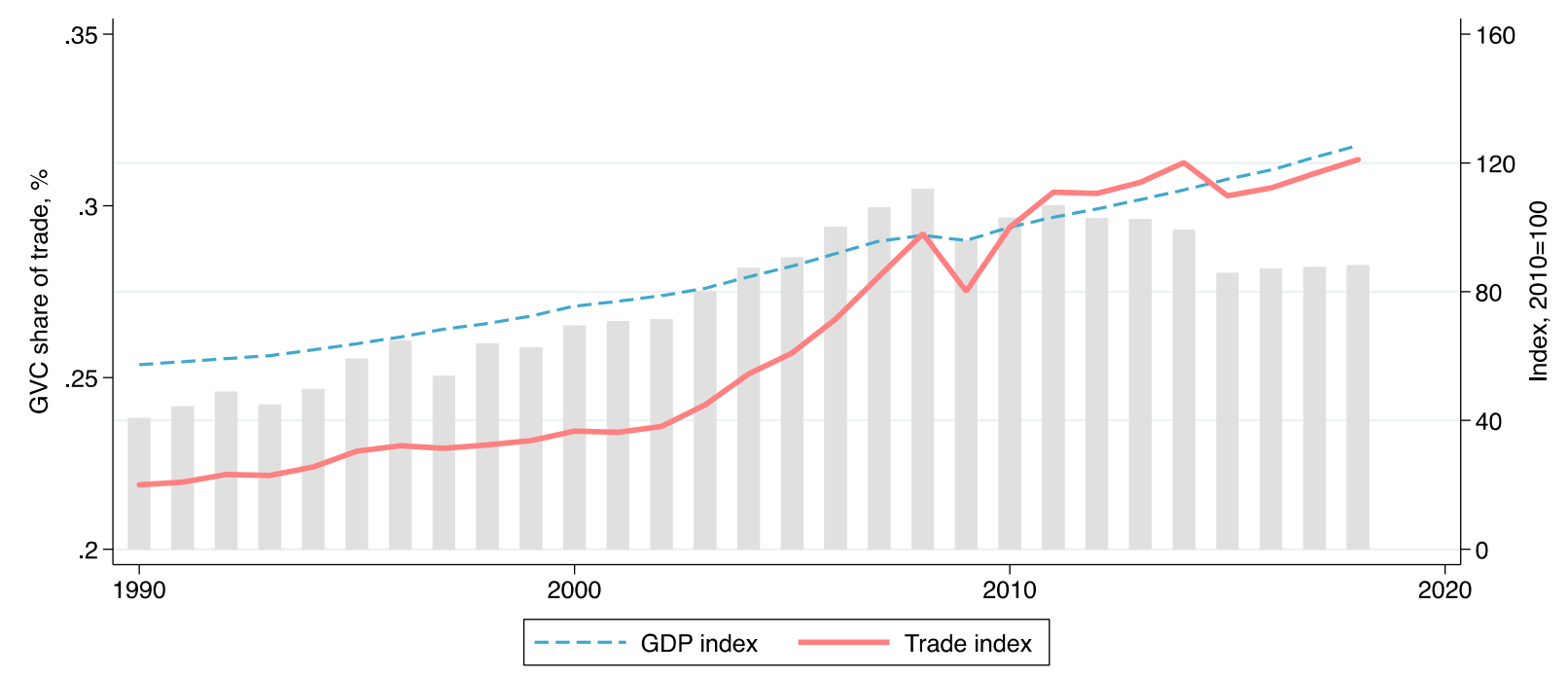

Source: The Eora Global Supply Chain Database, UNCTAD (2020) and the World Bank (2020). Trade is global exports of goods and services. GVC share of trade is proxied by the share of foreign value added in exports, based on the UNCTAD-Eora GVC database (Casella et al., 2019).

\footnotetext{
${ }^{9}$ See UNCTAD (2020).
} 


\section{Conclusion}

Contributing to the macroeconomic theory of the health driven crises, Guerrieri et al (2020) demonstrate in a general equilibrium setting, that supply shock, such as Covid-19, can trigger changes in aggregate demand larger than the shocks themselves. This is possible when supply shocks are concentrated in certain sectors, as they are during a shutdown in response to a pandemic. The fact that some goods are no longer available makes it less attractive to spend overall. An interpretation is that the shutdown increases the shadow price of the goods in the affected sectors, making total current consumption more expensive and thus discouraging it. On the other hand, the unavailability of goods in some sectors can shift spending towards the other sectors, through a substitution channel. Whether or not full employment is maintained in the sectors not directly affected by the shutdown depends on the relative strength of these two effects. A supply shock in sector 1 can spill over into a demand shortage in sector 2 that is amplified by incomplete markets. Guerrieri et al (2020) then turn to borrowing constrained consumers and show that the condition for a contraction in employment in unaffected sectors becomes less stringent. Intuitively, if workers in the affected sectors lose their jobs and income, their consumption drops significantly if they are credit constrained and have high MPCs. To make up for this, workers in the unaffected sectors would have to increase their consumption of the remaining goods sufficiently. This requires a higher degree of substitution across sectors. If goods are not too close substitutes, aggregate demand contracts more than supply and employment in the unaffected sectors falls.

\section{Appendix: Israel's financial integration with the world financial}

\section{markets}


Figure A: Cross country standard deviation of the real interest rate (adjusted by the real exchange rate changes): Israel and the US

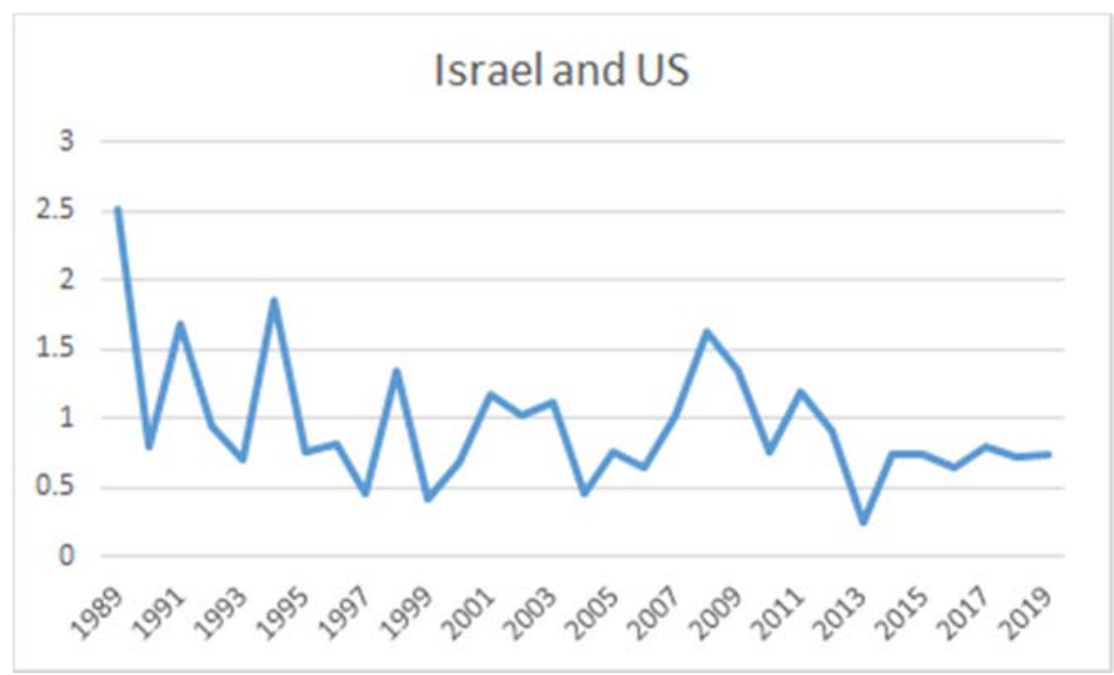

Source: Stats Bureau, FRED, World Bank, Real-exchange-rate adjusted, yields on three-month government bonds for Israel, and the yields on three-month US government bonds.

The globalization process that Israel took is covered in Razin (2018). The Figure shows that, except the GFC period, The Israel-US dispersion is trending down. The downward trend indicates the steady integration of the Israel's financial market into the world financial market; primarily that of the US.

\section{References}

Auer, R., C. Borio, and A. Filardo (2017). The globalization of inflation: the growing importance of global value chains. BIS Working Papers.

Bureau of Economic Analysis (2020). US Gross domestic product. https://apps. bea.gov/iTable/iTable.cfm?reqid=19\&step=2.

Carney, M. (2015, August). How is inflation affected by globalisation? WEF . 
Casella, B., R. Bolwijn, D. Moran, and K. Kanemoto (2019). Improving the analy- sis of global value chains: the UNCTAD-Eora Database. UNCTAD Transnational Corporations Journal.

Chetty, R., J. N. Friedman, N. Hendren, M. Stepner, and T. O. I. Team (2020, June). How did covid-19 and stabilization policies affect spending and employment? a new real-time economic tracker based on private sector data. Working Paper 27431, National Bureau of Economic Research.

De-Grauwe, P. and Y. Ji (2020, September). A tale of three depressions. VoxEU \& CEPR.

Eichengreen, B. and K. O’Rourke (2010, March). A tale of two depressions: What do the new data tell us? february 2010 update. VoxEU \& CEPR.

Guerrieri, V., G. Lorenzoni, L. Straub, and I. Werning (2020, April). Macroeco- nomic implications of covid-19: Can negative supply shocks cause demand shortages? Working Paper 26 Irwin, D A (1998), "The Smoot-Hawley Tari: A Quantitative Assessment," The Review of Economics and Statistics 80: 326-334.

Irwin, D A (2013), "The Nixon Shock After Forty Years: the Import Surcharge Revisited," World Trade Review 12: 29-56

Kilic, K. and D. Marin (2020, May). How covid-19 is transforming the world economy. VoxEU \& CEPR.

National Bureau of Statistics fo China (2020). Industrial production opera- tion in august 2020. http://www.stats.gov.cn/english/PressRelease/202009/ t20200916_1789764.html.

OECD (2020). Oecd.stat. https://stats.oecd.org/.

Razin, Assaf. (2018). Israel and the world economy: the power of globalisation. Cambridge,

MA: The MIT Press.

Reinhart, C. M. and K. S. Rogoff (2014, January). Recovery from financial crises: Evidence from 100 episodes. Working Paper 19823, National Bureau of Economic Research.

UNCTAD (2020). World Investment Report 2020: International Production Beyond the Pandemic. New York and Geneva: United Nations: UNCTAD.

World Bank (2020). Global Economic Prospects. https://www.worldbank.org/en/ publication/global-economic-prospects.

Zhan, J., R. Bolwijn, B. Casella, and A. U. Santos-Paulino (2020, August). Global value chain transformation to 2030: Overall direction and policy implications. VoxEU \& CEPR. 
